\title{
Ideas and perspectives: how coupled is the vegetation to the boundary layer?
}

\author{
Martin G. De Kauwe ${ }^{1,2}$, Belinda E. Medlyn ${ }^{3}$, Jürgen Knauer ${ }^{4}$, and Christopher A. Williams ${ }^{5}$ \\ ${ }^{1}$ ARC Centre of Excellence for Climate Extremes, University of New South Wales, Sydney, NSW 2052, Australia \\ ${ }^{2}$ Department of Biological Science, Macquarie University, North Ryde, NSW 2109, Australia \\ ${ }^{3}$ Hawkesbury Institute for the Environment, Western Sydney University, Locked Bag 1797, Penrith, NSW 2751, Australia \\ ${ }^{4}$ Department of Biogeochemical Integration, Max Planck Institute for Biogeochemistry, 07745 Jena, Germany \\ ${ }^{5}$ Graduate School of Geography, Clark University, 950 Main Street, Worcester, MA 01602, USA
}

Correspondence to: Martin G. De Kauwe (mdekauwe@gmail.com)

Received: 11 May 2017 - Discussion started: 17 May 2017

Revised: 1 September 2017 - Accepted: 6 September 2017 - Published: 9 October 2017

\begin{abstract}
Understanding the sensitivity of transpiration to stomatal conductance is critical to simulating the water cycle. This sensitivity is a function of the degree of coupling between the vegetation and the atmosphere and is commonly expressed by the decoupling factor. The degree of coupling assumed by models varies considerably and has previously been shown to be a major cause of model disagreement when simulating changes in transpiration in response to elevated $\mathrm{CO}_{2}$. The degree of coupling also offers us insight into how different vegetation types control transpiration fluxes, which is fundamental to our understanding of land-atmosphere interactions. To explore this issue, we combined an extensive literature summary from 41 studies with estimates of the decoupling coefficient estimated from FLUXNET data. We found some notable departures from the values previously reported in single-site studies. There was large variability in estimated decoupling coefficients (range 0.05-0.51) for evergreen needleleaf forests. This is a result that was broadly supported by our literature review but contrasts with the early literature which suggests that evergreen needleleaf forests are generally well coupled. Estimates from FLUXNET indicated that evergreen broadleaved forests were the most tightly coupled, differing from our literature review and instead suggesting that it was evergreen needleleaf forests. We also found that the assumption that grasses would be strongly decoupled (due to vegetation stature) was only true for high precipitation sites. These results were robust to assumptions about aerodynamic conductance and, to a lesser extent, energy balance closure. Thus, these data form a benchmarking metric
\end{abstract}

against which to test model assumptions about coupling. Our results identify a clear need to improve the quantification of the processes involved in scaling from the leaf to the whole ecosystem. Progress could be made with targeted measurement campaigns at flux sites and greater site characteristic information across the FLUXNET network.

\section{Introduction}

Predicting the response of transpiration to global change and the subsequent feedback to climate remains a major challenge for Earth system models (Zhu et al., 2017). Improving our understanding of how stomatal controls on transpiration vary between vegetation types is fundamental to simulating land-atmosphere interactions. Experimental evidence strongly indicates that stomatal conductance $\left(G_{\mathrm{S}}\right)$ is generally reduced in response to elevated $\mathrm{CO}_{2}$ (Morison, 1985; Medlyn et al., 2001; Ainsworth and Rogers, 2007) due to either a decrease in stomatal aperture with the reduced photosynthetic demand for $\mathrm{CO}_{2}$ and/or a change in stomatal density (McElwain and Chaloner, 1995; Woodward and Kelly, 1995). In models, incorporating this leaf-level reduction in $G_{\mathrm{S}}$ commonly results in predictions of decreased transpiration and increased run-off at global scales (Gedney et al., 2006; Betts et al., 2007; Cao et al., 2010). However, the magnitude of this effect varies strongly among models because the sensitivity of transpiration to a change in $G_{\mathrm{S}}$ depends on the assumption made about the strength of coupling 
of the vegetation to the surrounding boundary layer (McNaughton and Jarvis, 1983; Jarvis and McNaughton, 1986; McNaughton and Jarvis, 1991; Jacobs and De Bruin, 1992). De Kauwe et al. (2013) identified differences in the degree of coupling to be a major cause of disagreement among 11 model predictions of transpiration in response to elevated $\mathrm{CO}_{2}$ at two forest Free-Air $\mathrm{CO}_{2}$ Enrichment (FACE) experiments in the USA. Consequently, resolving this discrepancy among models in their assumptions of vegetationatmosphere coupling is key to reducing model uncertainty in future predictions of changes in transpiration.

The degree of coupling between vegetation and the atmosphere is commonly expressed by the decoupling factor $(\Omega$; Jarvis and McNaughton, 1986). If the decoupling factor is high, transpiration is more strongly controlled by incoming radiation and less by changes in $G_{\mathrm{s}}$. Low-stature canopies and species with large leaves are expected to be more decoupled (high $\Omega$ ) than tall-stature canopies and species with small leaves. This occurs because (i) small-stature canopies decrease the surface roughness, and hence the aerodynamic conductance, and (ii) large leaves decrease the leaf boundary layer conductance. Both act to diminish the rate of exchange between the vegetation surface and the atmosphere. Other characteristics of the vegetation, including foliage clumping, leaf shape, canopy density, and the vertical canopy distribution, will also alter the coupling. Values given in the literature for coniferous forests are typically low at $\Omega=\sim 0.1-0.2$ (Whitehead et al., 1984; Jarvis, 1985; Lee and Black, 1993; Meinzer et al., 1993). Values are typically higher for deciduous broadleaved species at $\Omega=0.2-0.4$ (Magnani et al., 1998; Wullschleger et al., 2000), evergreen broadleaved species at $\Omega=0.4-0.9$ (Meinzer et al., 1997; Wullschleger et al., 1998), grasses at $\Omega=0.8$ (McNaughton and Jarvis, 1983), and crops at $\Omega=0.2-0.9$ (Black et al., 1970; Brown, 1976; Meinzer et al., 1993; Mielke et al., 1999). These literature estimates of the degree of coupling are wide and thus do not offer a clear constraint to models. Furthermore, methods to estimate $\Omega$ often differ across studies, which complicates interpretations about variation across plant functional types. Single studies that have employed a consistent method to estimate $\Omega$ across multiple species are rare (e.g. Stoy et al., 2006; Khatun et al., 2011).

There has been considerable recent effort to develop better global datasets of stomatal behaviour for use by the modelling community (Lin et al., 2015; Miner et al., 2017). However, constraining the coupling between stomatal conductance and transpiration is equally important. For example, De Kauwe et al. (2015) demonstrated modest changes in transpiration when using the Lin et al. (2015) dataset to constrain the parameterization of $G_{\mathrm{s}}$ in the Community Atmosphere Biosphere Land Exchange (CABLE) land surface model. The CABLE model assumes a relatively weak level of coupling (De Kauwe et al., 2013). It is likely that models that assume stronger coupling (e.g. the Joint UK Land Envi- ronment Simulator, JULES; Best et al., 2011) would obtain different results.

To shed new light on this important question of vegetation-atmosphere coupling, we used eddy covariance data from FLUXNET to estimate the $\Omega$ coefficient for different plant functional types (PFTs). We aimed to (i) examine whether decoupling coefficients estimated from FLUXNET were consistent with literature values and (ii) develop a benchmark metric against which to test model assumptions about coupling.

\section{Materials and methods}

\subsection{Flux data}

Half-hourly eddy covariance measurements of the exchange of carbon dioxide, energy, and water vapour were obtained from the FLUXNET "La Thuile" Free and Fair dataset (http: //www.fluxdata.org). We estimated the degree of decoupling (Jarvis and McNaughton, 1986) as

$$
\Omega=\frac{1+\epsilon}{1+\epsilon+\frac{G_{\mathrm{a}}}{G_{\mathrm{s}}}},
$$

where $\epsilon=s / \gamma, s$ is the slope of the saturation vapour pressure curve at air temperature $\left(\mathrm{Pa} \mathrm{K}^{-1}\right), \gamma$ is the psychrometric constant $\left(\mathrm{Pa} \mathrm{K}^{-1}\right)$, and $G_{\mathrm{a}}\left(\mathrm{mol} \mathrm{m}^{-2} \mathrm{~s}^{-1}\right)$ is the aerodynamic conductance.

We estimated values of $G_{\mathrm{s}}$ by inverting the PenmanMonteith equation using measured latent heat (LE) flux for all datasets in which the net radiation $\left(R_{\mathrm{n}} ; \mathrm{W} \mathrm{m}^{-2}\right)$ and the frictional velocity $\left(u_{*} ; \mathrm{m} \mathrm{s}^{-1}\right)$ were available:

$$
G_{\mathrm{s}}=\frac{G_{\mathrm{a}} \gamma \lambda E}{s\left(R_{\mathrm{n}}-G\right)-(s+\gamma) \lambda E+G_{\mathrm{a}} M_{\mathrm{a}} c_{\mathrm{p}} D},
$$

where $E\left(\mathrm{~mol} \mathrm{~m}^{-2} \mathrm{~s}^{-1}\right)$ is the canopy transpiration, $\lambda$ is the latent heat of vaporization $\left(\mathrm{J} \mathrm{mol}^{-1}\right), D(\mathrm{~Pa})$ is the vapour pressure deficit, $G\left(\mathrm{~W} \mathrm{~m}^{-2}\right)$ is the soil heat flux, $M_{\mathrm{a}}$ $\left(\mathrm{kg} \mathrm{mol}^{-1}\right)$ is molar mass of air, and $c_{\mathrm{p}}$ is the heat capacity of air $\left(\mathrm{J} \mathrm{kg}^{-1} \mathrm{~K}^{-1}\right)$. At sites where values of $G$ were not available, $G$ was set to zero.

$G_{\mathrm{a}}$ was calculated following Thom (1975):

$$
G_{\mathrm{a}}=\frac{\mathrm{c}}{\frac{u}{u_{*}^{2}}+6.2 u_{*}^{-\frac{2}{3}}},
$$

where the first term in the denominator of Eq. (3) represents the turbulent aerodynamic resistance $\left(G_{\mathrm{am}}\right)$, the second term represents the canopy boundary layer component $\left(G_{\mathrm{b}}\right)$, $c=P /\left(R_{\mathrm{gas}} T_{\mathrm{k}}\right)$ is a conversion factor from units of $\mathrm{m} \mathrm{s}^{-1}$ to $\mathrm{mol} \mathrm{m}{ }^{-2} \mathrm{~s}^{-1}, P$ is atmospheric pressure (Pa), $R_{\text {gas }}$ is the gas constant $\left(\mathrm{J} \mathrm{mol}^{-1} \mathrm{~K}^{-1}\right), T_{\mathrm{k}}$ is the air temperature in Kelvin, and $u\left(\mathrm{~m} \mathrm{~s}^{-1}\right)$ is the wind speed.

In our analysis we derived the average (three most productive months) decoupling coefficient as the focus of our paper 
was on the spatial variability in coupling across FLUXNET. This is likely a metric that can be readily exploited to assess existing coupling assumptions in models. In the future, researchers may wish to explore the temporal variability in this metric.

The approach we have taken (similar to Jarvis and McNaughton, 1986) ignores differences between canopy and air temperature (radiative coupling) within the canopy (see Martin, 1989). However, correcting for the longwave radiative conductance $\left(G_{\mathrm{r}}\right)$ mostly impacts vegetation with the weakest control on transpiration, and as a result this assumption has little impact on the degree of coupling range for forest species but may be a factor for other species.

Flux data were first screened as follows: (i) data flagged as "good" (quality control flag "fqcOK" = 1; Williams et al., 2012); (ii) data from the three most productive months to account for the different timing of summer in the Northern and Southern hemispheres; (iii) daylight hours between 08:00 am and 04:00 pm to account for periods when the vegetation is photosynthesizing; (iv) half hours with precipitation and the subsequent 48 half hours were excluded to minimize the influence of soil evaporation (Law et al., 2002; Groenendijk et al., 2011; Dekker et al., 2016); and (v) data with $u_{*}<0.25$ were excluded to avoid conditions of low turbulence (Sánchez et al., 2010). We also excluded sites classified as mixed forest, permanent wetlands, or those where the PFT was unclassified.

Pressure was estimated using the hypsometric equation based on site elevation data. Where site elevation information was missing, values were gap-filled using the 30 arcsec $(\sim 1 \mathrm{~km})$ global digital elevation model GTOPO30 data from the United States Geological Survey (USGS). After filtering, 164 sites and 592 site years remained.

We also tested the sensitivity of estimated values to (i) errors in $G_{\mathrm{a}}$ and (ii) errors due to a lack of energy balance closure. Firstly, we increased and decreased estimated values of $G_{\mathrm{a}}$ by $30 \%$ to examine the sensitivity of $G_{\mathrm{s}}$ values inverted from the Penman-Monteith equation. Secondly, following the recommendations by Wohlfahrt et al. (2009), we tested the sensitivity of our results to energy balance closure by correcting fluxes using the Bowen-ratio method (each halfhourly LE and $H$ flux) based on the available energy $\left(R_{\mathrm{n}}-G\right)$ on a longer timescale (three most productive months).

We also replicated our analysis using eddy covariance data taken from the FLUXNET2015 dataset (http://fluxnet. fluxdata.org/data/fluxnet2015-dataset). Figure A1 in the Appendix is a replicate of Fig. 1 and shows that the patterns we derived are robust across flux releases.

\subsection{Results}

We summarized previously reported estimates of the decoupling coefficient from 41 studies in Tables 1 and A2 in the Appendix. Broadly speaking, estimated decoupling coefficients from FLUXNET (Fig. 1) differed among PFTs in line
Table 1. Literature summary of decoupling coefficients; see Table A2 for summaries of individual studies. Plant functional types (PFT) are defined as ENF - evergreen needleleaf forest, EBF - evergreen broadleaved forest, DBF - deciduous broadleaved forest, TRF - tropical rain forest, SAV - savanna, SHB - shrub, GRA grasses, $\mathrm{C} 3 \mathrm{C}-\mathrm{C}_{3}$ crops, and $\mathrm{C} 4 \mathrm{C}-\mathrm{C}_{4}$ crops.

\begin{tabular}{lrrrrr}
\hline PFT & Mean & SD & Min & Max & $\begin{array}{r}\text { Number of } \\
\text { studies }\end{array}$ \\
\hline ENF & 0.19 & 0.1 & 0.06 & 0.43 & 13 \\
EBF & 0.26 & 0.13 & 0.1 & 0.63 & 12 \\
DBF & 0.36 & 0.18 & 0.1 & 0.7 & 11 \\
TRF & 0.57 & 0.28 & 0.25 & 0.9 & 11 \\
SAV & 0.14 & - & - & - & 1 \\
SHB & 0.27 & 0.19 & 0.13 & 0.4 & 2 \\
GRA & 0.42 & 0.23 & 0.21 & 0.8 & 4 \\
C3C & 0.4 & 0.28 & 0.2 & 0.59 & 2 \\
C4C & 0.58 & - & - & - & 1 \\
\hline
\end{tabular}

with literature values (Tables 1 and A2) and in line with expectations related to vegetation roughness and/or stature. Evergreen needleleaf forests (ENFs), which have small leaves, were in general tightly coupled (low $\Omega$ ), while deciduous broadleaved forests, tropical rain forest (large leaves), and grasses and crops (small stature) had a lower degree of coupling (higher $\Omega$ ). However, there were some notable departures from expectations. Estimates derived from FLUXNET indicated that evergreen broadleaf forests were the most coupled PFT (mean $\Omega=0.21$ ) as opposed to the literature review, which suggested that ENF PFTs were the most coupled (mean $\Omega=0.19$ ). The FLUXNET data also indicated unexpectedly wide ranges for $\Omega$ within PFTs. For grasses, $\Omega$ ranged from $0.02-0.8$; the number of low values was particular surprising given the expectation that shorter-stature vegetation would be more decoupled.

The wide range in estimated values for ENF sites was also striking; $\Omega$ extended from 0.05 to 0.51 . To attempt to better understand this range, we first separated ENF sites into the following: (i) sites with a low inter-annual coefficient of variation $(20 \%)$, indicating consistent year-to-year estimates of the degree of coupling; (ii) sites with a coefficient of variation $>20 \%$, indicating sites with year-to-year variability in coupling; and (iii) sites with only 2 years of data. This separation was intended to rule out sampling issues. Figure 2 shows that the variability in the estimated decoupling coefficient cannot be explained by sampling bias; there is significant site-to-site variability regardless of the inter-annual variability.

We then probed these results for relationships with site variables by testing to see if (i) sites with higher precipitation (in the three most productive months) were more decoupled when precipitation was assumed to be a proxy for leaf area index (LAI) and productivity or (ii) windy sites were more coupled. For grasses we found a significant relationship between the degree of coupling and precipitation (Fig. 3). The 


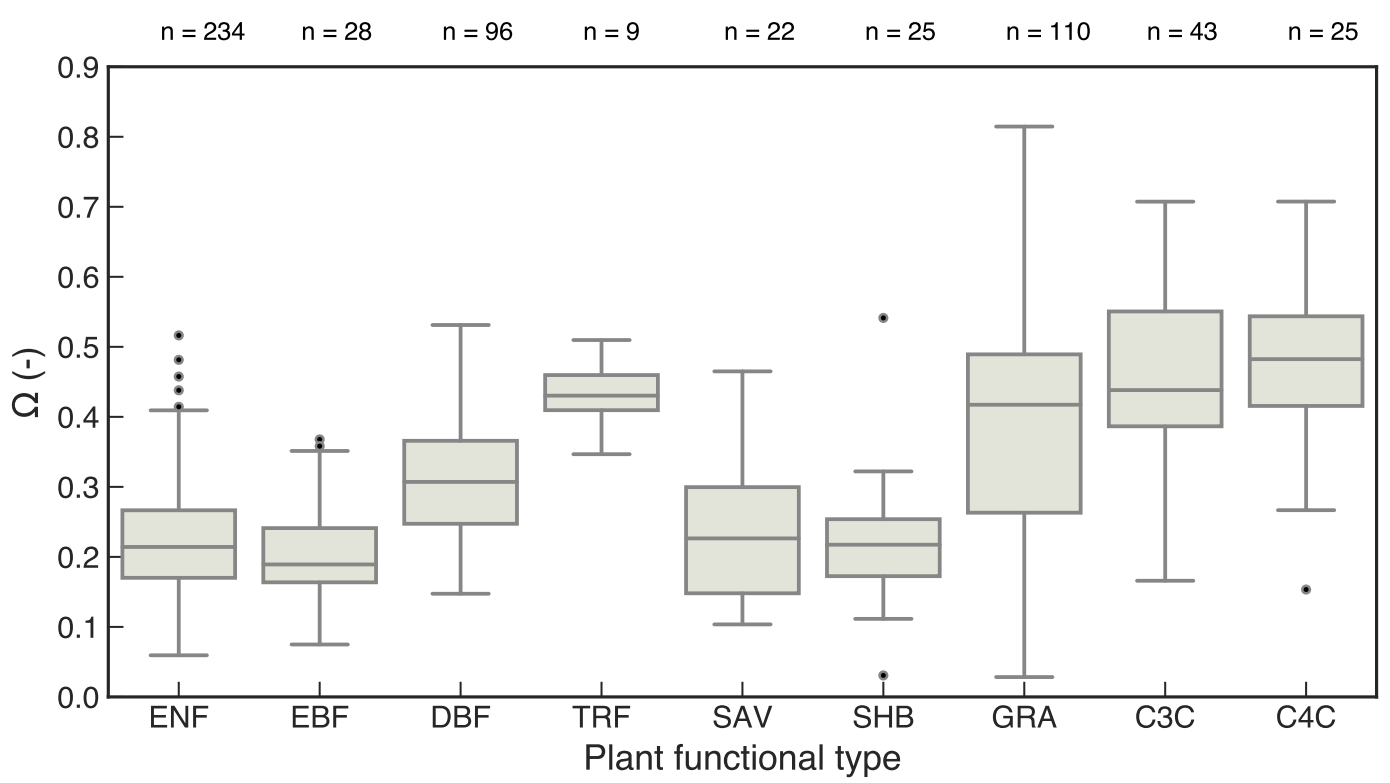

Figure 1. Box and whisker plot (line, median; box, inter-quartile range) showing the estimated coupling coefficient $(\Omega)$ from FLUXNET data grouped by plant functional type. Whiskers extend to 1.5 times the inter-quartile range, with dots outside of the whiskers showing outliers. Plant functional types are defined as ENF - evergreen needleleaf forest, EBF - evergreen broadleaved forest, DBF - deciduous broadleaved forest, TRF - tropical rain forest, SAV - savanna, SHB - shrub, GRA - grasses, C3C - $\mathrm{C}_{3}$ crops, and C4C - $\mathrm{C}_{4}$ crops. Values of $n$ indicate the number of site years for FLUXNET.

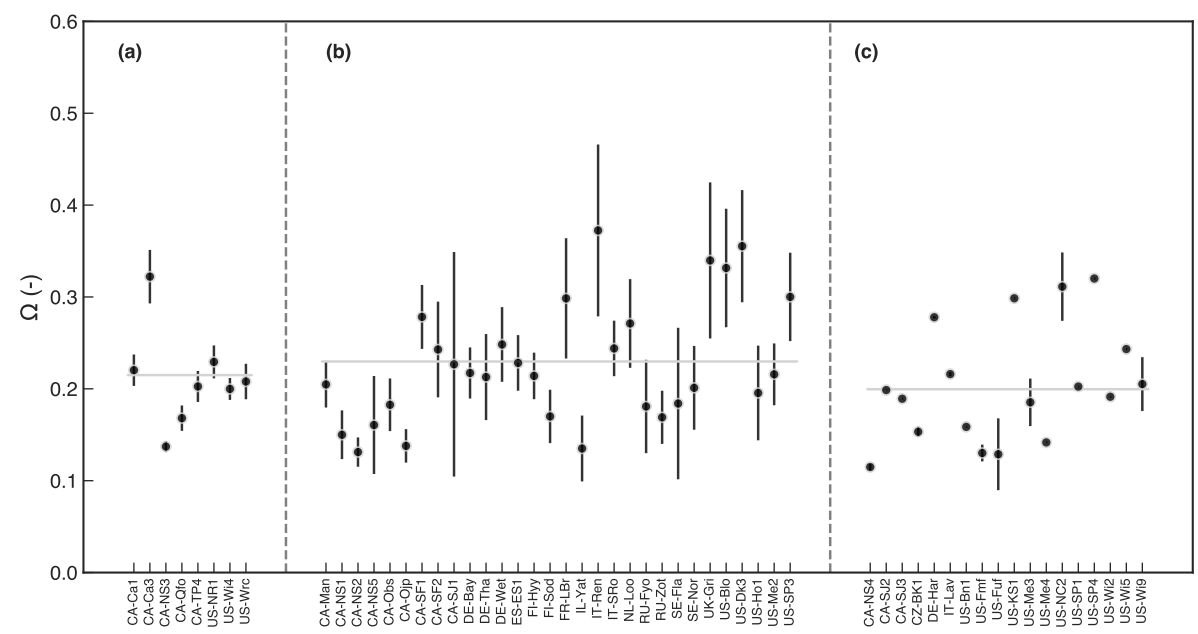

Figure 2. Values of the coupling coefficient $(\Omega)$ for sites from the evergreen needleleaf forest (ENF) plant functional type. Estimated values of $\Omega$ have been split into (a) sites where the coefficient of variation (COV) is $<20 \%$, (b) sites where the COV is $>20 \%$, and (c) sites with only 2 years of data. Site error bars represent 1 standard deviation (site year variation) in estimated $\Omega$ values. Solid horizontal grey lines show overall mean coupling coefficients.

data suggest that for sites that are likely to be more open grasslands (i.e. sites with low precipitation), the vegetation is very coupled to the atmosphere, with a high level of stomatal control. This relationship between the degree of coupling and precipitation $(r=0.46)$ explains the high variability in estimated decoupling coefficients for grasses as shown in Fig. 1. The prediction that grasses would be weakly coupled due to small vegetation stature only holds true at sites with high 3 - month precipitation, which are presumably sites with high LAI. We also found a significant relationship for ENF sites $(r=0.40)$ and deciduous broadleaved forests $(r=0.64)$, suggesting that the degree of coupling declined with canopy density. We also found evidence of a weak negative relationship ( $r=-0.21$ ) between wind speed and the degree of coupling for forest sites, i.e. windier sites tended to be more coupled 


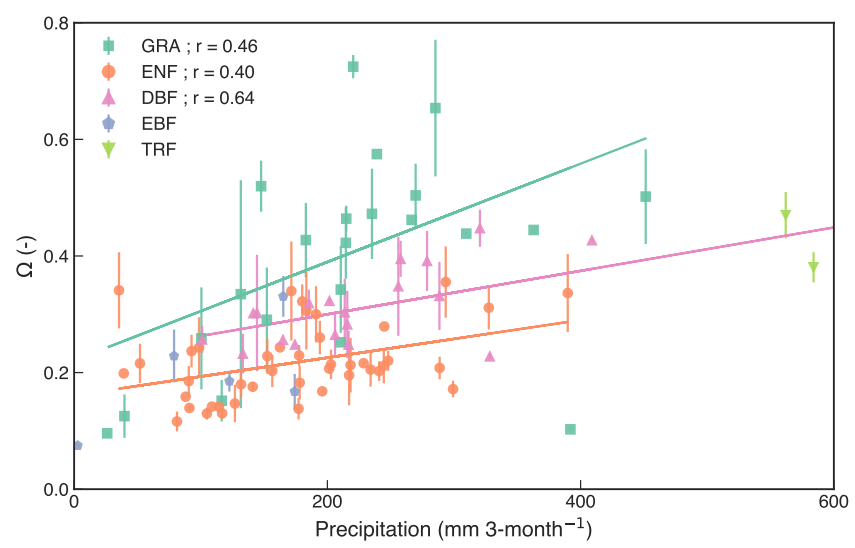

Figure 3. Values of the estimated coupling coefficient $(\Omega)$ for forest (ENF, EBF, DBF, TRF) vegetation and grasses as a function of precipitation in the three most productive months. Only data for $90 \%$ of the three most productive months were flagged as "good" and are shown. Lines indicate statistically significant regressions $(P<0.05)$. Plant functional types are defined as GRA - grasses, ENF - evergreen needleleaf forest, EBF - evergreen broadleaved forest, $\mathrm{DBF}$ - deciduous broadleaved forest, and TRF - tropical rain forest.

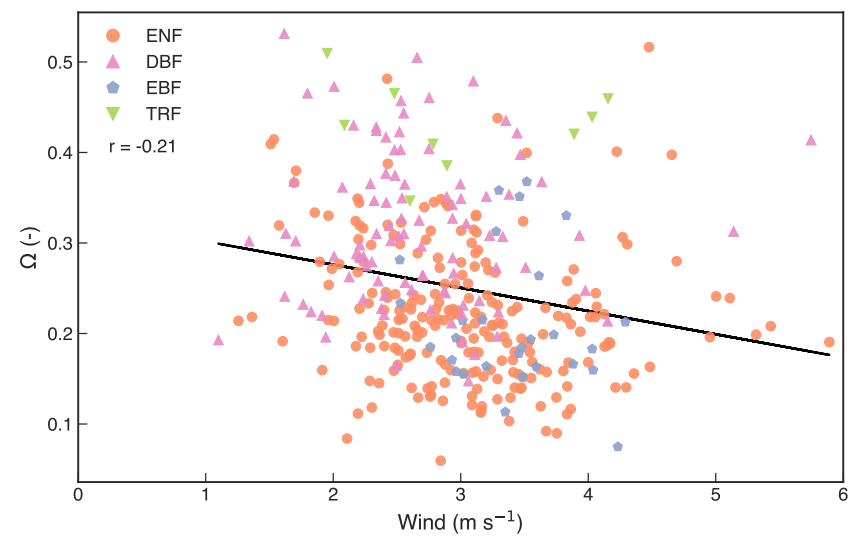

Figure 4. Values of the estimated coupling coefficient $(\Omega)$ for forest (ENF, EBF, DBF, TRF) vegetation as a function of wind speed. Line indicates statistically significant regression $(P<0.05)$, and $r$ is the correlation coefficient. Plant functional types are defined as ENF - evergreen needleleaf forest, EBF - evergreen broadleaved forest, $\mathrm{DBF}$ - deciduous broadleaved forest, and TRF - tropical rain forest.

(Fig. 4). For non-forest PFTs, we did not find a significant relationship between wind speed and coupling.
Finally, we examined the sensitivity of our results to potential errors. We tested whether our results were sensitive to different estimates of $G_{\mathrm{a}}$ and whether our estimates of $G_{\text {s }}$ were sensitive to energy imbalance. We found that the broad pattern of our results in Fig. 1 was insensitive to errors in $G_{\mathrm{a}}$. Increasing or decreasing $G_{\mathrm{a}}$ by $30 \%$ led to the median decoupling coefficient decreasing or increasing by roughly 0.05 for evergreen broadleaf forest (EBF) sites, for example. However, we did find that our results were sensitive to a correction for the lack of energy balance closure. Figure A2 shows that attempting to correct for a lack of closure leads to sites becoming less coupled, but it does not shift the between-PFT differences in the degree of coupling. The largest changes were for $C_{3}$ crops $(\Omega$ changed from $\sim 0.44$ to $\sim 0.6$ ) and deciduous broadleaved forests ( $\Omega$ changed from $\sim 0.31$ to $\sim 0.41$ ).

\subsection{Discussion}

Correctly characterizing the sensitivity of transpiration to $G_{\mathrm{s}}$ is critical for simulating the water cycle, particularly for future projections of the terrestrial biosphere where it is widely expected that $G_{\mathrm{S}}$ will decrease in response to increasing atmospheric $\mathrm{CO}_{2}$. The parameterization of this crucial link between leaf- and canopy-scale water fluxes has been largely ignored in model studies addressing the impact of elevated $\mathrm{CO}_{2}$ (Betts et al., 2007; Cao et al., 2010; Zhu et al., 2017). Resulting projections of changes in transpiration and associated fluxes (e.g. run-off, precipitation) are likely to be model specific, with large uncertainty among models (De Kauwe et al., 2013). Model studies rarely provide information about the degree of coupling assumed within the model. The range of assumptions commonly incorporated in models includes the following: (i) coupling as a function of roughness length (determined by vegetation height), e.g. JULES; (ii) coupling as a function of leaf size, e.g. CLM (the Community Land Model; Oleson et al., 2013); (iii) coupling as affected by within-canopy turbulence, e.g. CABLE (Raupach et al., 1997; Kowalczyk et al., 2006); (iv) some combination of all three, e.g. CABLE/CLM; (v) coupling that is not sensitive to wind speed (i.e. wind speed is fixed to $5 \mathrm{~m} \mathrm{~s}^{-1}$ ), e.g. SDGVM (Sheffield Dynamic Global Vegetation Model; Woodward et al., 1995); or (vi) models that use an alternative to the Penman-Monteith equation, e.g. LPJ (Lund-PotsdamJena family of models; Sitch et al., 2003). This family of models uses an empirically calibrated hyperbolic function of canopy conductance (Huntingford and Monteith, 1998) and the implied level of coupling depends on how this function is parameterized.

Understandably, the pioneering work of Jarvis and McNaughton (1986) is widely cited when issues of coupling are discussed in the literature. However, many of the earlier estimates of coupling they summarized were taken from single sites and thus do not necessarily reflect the diversity of global vegetation. In this study we have summarized 
41 literature studies in combination with estimates of the decoupling coefficient from 164 sites and 592 site years from FLUXNET. Our literature summary (Tables 1 and A2) highlights the diversity of approaches used to determine $\Omega$. In contrast, we have applied a consistent methodology across all 164 FLUXNET sites. For forest PFTs, our results point to a weaker level of coupling than is often assumed. Notably, ENF species were found to be less coupled (mean $\Omega=$ 0.21 ; range 0.05-0.51) across FLUXNET than summarized in Jarvis and McNaughton (1986) $(\Omega=0.1)$. Our estimate derived from FLUXNET was supported by our wider literature summary $(n=13)$. We found that the often-assumed low degree of coupling for grasses is likely to only be true for high precipitation (and presumably high LAI) sites; low precipitation sites were strongly coupled. A further plausible explanation is that these drier sites are limited by available soil moisture, with lower $G_{\mathrm{s}}$ resulting in a high degree of coupling. We could not easily explain the coupling values estimated for evergreen broadleaf forests, which were estimated to be more coupled than evergreen needleleaf forests; this is a break from theoretical understanding developed from vegetation roughness and/or stature. Finally, grouping the data by PFTs also highlighted marked within-PFT variation in the degree of coupling.

As land models move towards more realistic representations of the variability in stomatal conductance (De Kauwe et al., 2015) informed by leaf-level syntheses (Lin et al., 2015; Miner et al., 2017), it is also important that they accurately simulate the coupling between vegetation and the atmosphere. Without this focus, any efforts to improve realism at the leaf scale will not be reflected in improvements in simulated transpiration at the canopy scale.

\subsubsection{Caveats}

One criticism of the approach taken here is that we have assumed a big-leaf approximation to estimate the vegetation degree of coupling (see Raupach and Finnigan, 1988). It is of course likely that variation within a canopy in terms of micro-climate (i.e. vapour pressure deficit, irradiance, temperature), as well as how stomata respond, may invalidate this approach. The use of a big-leaf approximation could be a possible explanation for the surprisingly high level of coupling found in evergreen broadleaf forests, although it would appear unlikely given the weaker level of coupling found for deciduous broadleaved and tropical rainforest species.

We found high variation in the estimated coupling factor both across sites and within sites. Two assumptions we make with respect to the flux data could explain this variation. Firstly, we excluded data following rainfall (48 h) (Law et al., 2002; Groenendijk et al., 2011; Dekker et al., 2016) to minimize the effects of soil evaporation. Clearly, if soil evaporation is still a component of the LE flux after this point it would introduce error to our estimates. This assumption may also vary with PFT. Secondly, flux towers commonly do not close the energy balance (Foken, 2008; Wilson et al., 2002). Our use of the inverted Penman-Monteith equation implies that we are attributing any errors due to energy imbalance to the sensible heat flux (see Knauer et al., 2017). Additionally, where data on the soil heat flux were missing, we assumed there was no storage. Correcting for these issues is not straightforward as it requires determining which flux is the source of the error (see Wohlfahrt et al., 2009, for a detailed discussion). We followed the recommendations by Wohlfahrt et al. (2009) and tested the sensitivity of our results to energy balance closure by correcting using the Bowenratio method based on the available energy $\left(R_{\mathrm{n}}-G\right)$. Whilst we did find some sensitivity in our results (particularly for $\mathrm{C}_{3}$ crops and deciduous broadleaved forests), it did not change the ordering of coupling factors between PFTs or explain the unexpectedly high level of coupling for EBF sites.

Finally, we estimated the canopy aerodynamic conductance $\left(G_{\mathrm{a}}\right)$ using an empirical equation following Thom (1975). Knauer et al. (2017) tested the impact of different methods of estimating $G_{\mathrm{a}}$ from flux data on estimates of the stomatal slope parameter (the sensitivity of stomatal conductance to assimilation). They found that a more physically based representation of $G_{\text {a }}$ (Su et al., 2001) led to a lower estimate of $G_{\mathrm{a}}$ at two EBF flux sites and higher estimates of $G_{\mathrm{a}}$ at another EBF and a deciduous broadleaved site. We tested the sensitivity of our results to a change in $G_{\mathrm{a}}$ as shown by Knauer et al. (2017) and found the patterns in coupling to be robust across PFTs.

\subsubsection{Route forward}

Estimates of coupling from ecosystem-scale flux data are directly relevant for models. We previously speculated (De Kauwe et al., 2013) that discrepancies among models in coupling might be resolved by examining eddy covariance data. The range in coupling factors we have estimated from the FLUXNET data provides an overall constraint on the degree of coupling that should be assumed in models and an indication of the appropriate degree of variability in coupling across PFTs and rainfall regimes. The next steps involve determining what models currently assume about the degree of coupling and then to determine how flux-derived estimates of coupling would change model predictions.

In this study we examined the long-term average coupling factor. It may also be instructive to consider how estimated coupling factors change across the course of a day or within a season. However, it is likely that such an approach may be more sensitive to noise in the fluxes and events such as drought.

Our results also identify a clear need to better understand leaf-to-atmosphere coupling. We need to better understand why coupling factors vary within PFTs. There are a number of plausible explanations, such as drought, diversity of vegetation within a flux footprint, and data issues, and it is likely that more detailed site-specific insight will be required 
to move forward. To assist in better understanding patterns, we will need greater detail in terms of ancillary data from FLUXNET sites. We attempted to probe our results with respect to canopy height and LAI, but for many sites this information was not available. Other potentially useful information would include leaf size, stem density and crown length, and whether canopy height is static or increasing. These data would facilitate more sophisticated approaches to be explored: for example, estimates of $G_{\mathrm{b}}$ based on leaf size (Su et al., 2001). A more fundamental process understanding will require targeted $G_{\mathrm{s}}$ measurements throughout the canopy alongside corresponding sap flux measurements in forests and chamber measurements in grasslands. Recently, Medlyn et al. (2017) compared estimates of plant water-use efficiency derived from leaf gas exchange data and eddy flux data for eight sites where these measurements were acquired at the same point in time. They found similarities for DBF and TRF PFTs but differences for EBF and ENF PFTs. The authors were unable to explain these scaling discrepancies. Further targeted measurement campaigns at flux sites could lead to new knowledge, which would advance our understanding of the processes involved in scaling from the leaf to the canopy.

Code availability. All code is freely available from https://github. com/mdekauwe/flux_decoupling.

Data availability. All eddy covariance data are available from http: //fluxnet.fluxdata.org/data/la-thuile-dataset/. 


\section{Appendix A}

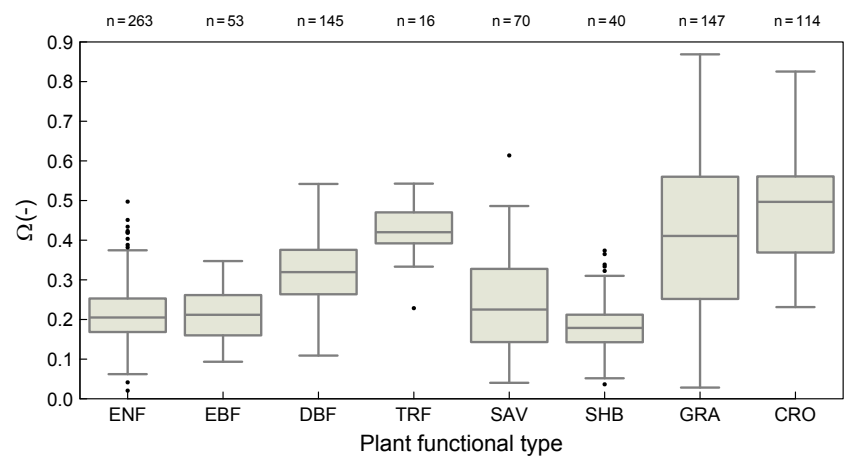

Figure A1. Box and whisker plot (line, median; box, interquartile range) showing the estimated coupling coefficient $(\Omega)$ from FLUXNET2015 data grouped by plant functional type. Whiskers extend to 1.5 times the inter-quartile range, with dots outside of the whiskers showing outliers. Plant functional types are defined as ENF - evergreen needleleaf forest, EBF - evergreen broadleaved forest, DBF - deciduous broadleaved forest, TRF - tropical rain forest, SAV - savanna, SHB - shrub, GRA - grasses, C3C - $\mathrm{C}_{3}$ crops, and $\mathrm{C} 4 \mathrm{C}-\mathrm{C}_{4}$ crops. Values of $n$ indicate the number of site years for FLUXNET.

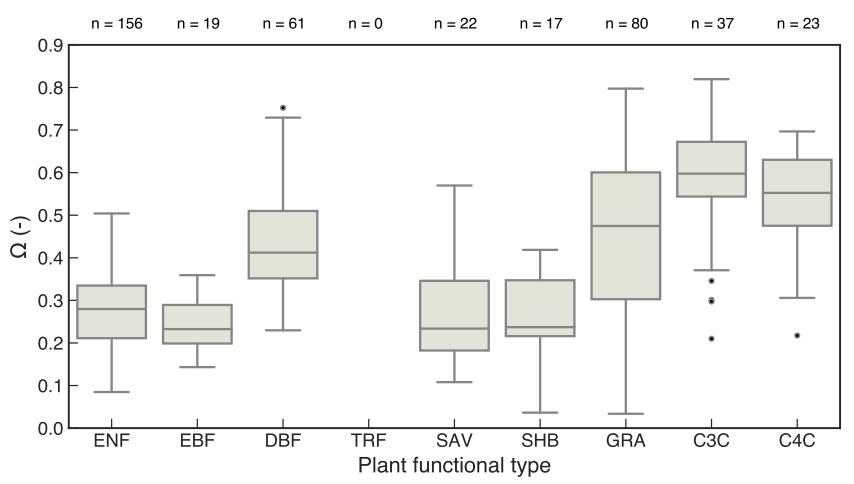

Figure A2. Box and whisker plot (line, median; box, interquartile range) showing the estimated coupling coefficient $(\Omega)$ from FLUXNET data grouped by plant functional type. These data have been corrected for energy imbalance by adjusting the Bowen-ratio method for the imbalance across the three most productive months. Whiskers extend to 1.5 times the inter-quartile range, with dots outside of the whiskers showing outliers. Plant functional types are defined as ENF - evergreen needleleaf forest, EBF - evergreen broadleaved forest, DBF - deciduous broadleaved forest, TRF tropical rain forest, SAV - savanna, SHB - shrub, GRA - grasses, $\mathrm{C} 3 \mathrm{C}-\mathrm{C}_{3}$ crops, and $\mathrm{C} 4 \mathrm{C}-\mathrm{C}_{4}$ crops. Values of $n$ indicate the number of site years for FLUXNET. 
Table A1. FLUXNET site years used in the analysis.

\begin{tabular}{|c|c|}
\hline Site ID & Years \\
\hline AT-Neu & 2002200320042005 \\
\hline AU-How & 20012002200320042006 \\
\hline AU-Tum & 200120022003200420052006 \\
\hline AU-Wac & 200520062007 \\
\hline BE-Lon & 200420052006 \\
\hline BW-Ghg & 2003 \\
\hline BW-Ghm & 2003 \\
\hline BW-Ma1 & 199920002001 \\
\hline CA-Ca1 & 19981999200020012002200320042005 \\
\hline $\mathrm{CA}-\mathrm{Ca} 3$ & 20012002200320042005 \\
\hline CA-Let & 19981999200020012002200320042005 \\
\hline CA-Man & 199419951997199819992000200120022003 \\
\hline CA-NS1 & 200220032004 \\
\hline CA-NS2 & 2002200320042005 \\
\hline CA-NS3 & 2001200220042005 \\
\hline CA-NS4 & 20032004 \\
\hline CA-NS5 & 20012002200320042005 \\
\hline CA-NS6 & 20012002200320042005 \\
\hline CA-Oas & 19971999200020012002200320042005 \\
\hline CA-Obs & 1999200020012002200320042005 \\
\hline CA-Ojp & 1999200020012002200320042005 \\
\hline CA-Qfo & 2003200420052006 \\
\hline CA-SF1 & 200320042005 \\
\hline CA-SF2 & 200320042005 \\
\hline CA-SJ1 & 200320042005 \\
\hline CA-SJ2 & 2005 \\
\hline $\mathrm{CA}-\mathrm{SJ} 3$ & 2005 \\
\hline CA-TP4 & 200320042005 \\
\hline CG-Tch & 2006 \\
\hline $\mathrm{CH}-\mathrm{Oe} 1$ & 200320042005 \\
\hline CN-Du1 & 20052006 \\
\hline CN-Du2 & 2006 \\
\hline CN-HaM & 20022003 \\
\hline $\mathrm{CN}-\mathrm{Xi1}$ & 2006 \\
\hline $\mathrm{CN}-\mathrm{Xi} 2$ & 2006 \\
\hline $\mathrm{CZ}-\mathrm{BK} 1$ & 20042005 \\
\hline $\mathrm{CZ}-\mathrm{BK} 2$ & 2004 \\
\hline DE-Bay & 1996199719981999 \\
\hline DE-Geb & 200420052006 \\
\hline DE-Gri & 20052006 \\
\hline DE-Hai & 2000200120022003200420052006 \\
\hline DE-Har & 20052006 \\
\hline $\mathrm{DE}-\mathrm{Kli}$ & 200420052006 \\
\hline DE-Meh & 2003200420052006 \\
\hline DE-Tha & 1996199719981999200020012002200320042005 \\
\hline DE-Wet & 20022003200420052006 \\
\hline DK-Fou & 2005 \\
\hline DK-Lva & 2005 \\
\hline DK-Ris & 2004 \\
\hline DK-Sor & 20042005 \\
\hline ES-ES1 & 200020022003200420052006 \\
\hline ES-ES2 & 200420052006 \\
\hline ES-LMa & 200420052006 \\
\hline ES-VDA & 200420052006 \\
\hline
\end{tabular}


Table A1. Continued.

\begin{tabular}{|c|c|}
\hline Site ID & Years \\
\hline FI-Hyy & 19981999200020012002200320042006 \\
\hline FI-Sod & 20022003200420052006 \\
\hline FR-Aur & 2005 \\
\hline FR-Fon & 20052006 \\
\hline FR-Gri & 20052006 \\
\hline FR-Hes & 1997199819992000200120022003200420052006 \\
\hline FR-LBr & 19961997199820002003200420052006 \\
\hline FR-Lam & 2005 \\
\hline FR-Lq1 & 2005 \\
\hline FR-Lq2 & 20042005 \\
\hline FR-Pue & 2000200120022003200420052006 \\
\hline GF-Guy & 200420052006 \\
\hline HU-Bug & 20022003200420052006 \\
\hline HU-Mat & 200420052006 \\
\hline ID-Pag & 20022003 \\
\hline IE-Ca1 & 200420052006 \\
\hline IE-Dri & 20042005 \\
\hline IL-Yat & 2001200220032006 \\
\hline IS-Gun & 199619971998 \\
\hline IT-Amp & 20022003200420052006 \\
\hline IT-BCi & 20052006 \\
\hline IT-Be2 & 2006 \\
\hline IT-Cas & 2006 \\
\hline IT-Col & 19981999200420052006 \\
\hline IT-Cpz & 19972000200120022003200420052006 \\
\hline IT-LMa & 200420052006 \\
\hline IT-Lav & 20042006 \\
\hline IT-MBo & 2003200420052006 \\
\hline IT-Mal & 2004 \\
\hline IT-Noe & 200420052006 \\
\hline IT-Non & 2001200220032006 \\
\hline IT-PT1 & 20032004 \\
\hline IT-Ren & 20002001200220032004 \\
\hline IT-Ro1 & 200020022003200420052006 \\
\hline IT-Ro2 & 200420052006 \\
\hline IT-SRo & 200020022003200420052006 \\
\hline IT-Vig & 2004 \\
\hline JP-Mas & 20022003 \\
\hline NL-Ca1 & 2003200420052006 \\
\hline NL-Hor & 2006 \\
\hline NL-Lan & 2005 \\
\hline NL-Loo & 199619971998199920012002200320042006 \\
\hline PT-Esp & 200220042006 \\
\hline PT-Mi1 & 2005 \\
\hline PT-Mi2 & 200420052006 \\
\hline RU-Cok & 2005 \\
\hline RU-Fyo & 1998199920022003200420052006 \\
\hline RU-Ha1 & 20032004 \\
\hline RU-Zot & 200220032004 \\
\hline SE-Abi & 2005 \\
\hline SE-Fla & 19961997199820012002 \\
\hline SE-Nor & 1996199719982005 \\
\hline UK-EBu & 2004 \\
\hline UK-ESa & 20042005 \\
\hline
\end{tabular}


Table A1. Continued.

\begin{tabular}{|c|c|}
\hline Site ID & Years \\
\hline UK-Gri & 1998200020012006 \\
\hline UK-Ham & 20042005 \\
\hline UK-Her & 2006 \\
\hline UK-PL3 & 20052006 \\
\hline US-ARM & 2003200420052006 \\
\hline US-Aud & 20022003200420052006 \\
\hline US-Bar & 20042005 \\
\hline US-Bkg & 200420052006 \\
\hline US-Blo & 199719981999200020012002200320042005 \\
\hline US-Bn1 & 2003 \\
\hline US-Bn2 & 2003 \\
\hline US-Bo1 & 199619971998199920002001200220032004200520062007 \\
\hline US-Bo2 & 200420052006 \\
\hline US-CaV & 20042005 \\
\hline US-Dk1 & 20012002200320042005 \\
\hline US-Dk2 & 20032004 \\
\hline US-Dk3 & 20012002200320042005 \\
\hline US-FPe & 2000200120022003200420052006 \\
\hline US-Fmf & 20052006 \\
\hline US-Fuf & 20052006 \\
\hline US-Fwf & 20052006 \\
\hline US-Goo & 20022003200420052006 \\
\hline US-Ha1 & 1992199319941995199619971998199920002001200320052006 \\
\hline US-Ho1 & 19961997199819992000200120022003 \\
\hline US-IB1 & 200520062007 \\
\hline US-IB2 & 200420062007 \\
\hline US-KS1 & 2002 \\
\hline US-KS2 & 20022003200420052006 \\
\hline US-MMS & 200020012002 \\
\hline US-MOz & 200420052006 \\
\hline US-Me2 & 200320042005 \\
\hline US-Me3 & 20042005 \\
\hline US-Me4 & 2000 \\
\hline US-NC2 & 20052006 \\
\hline US-NR1 & 1999200020022003 \\
\hline US-Ne1 & 20012002200320042005 \\
\hline US-Ne2 & 20012002200320042005 \\
\hline US-Ne3 & 2001200220032004 \\
\hline US-SO2 & 199719981999200420052006 \\
\hline US-SO3 & 1997199820052006 \\
\hline US-SP1 & 2005 \\
\hline US-SP3 & 199920002001200220032004 \\
\hline US-SP4 & 1998 \\
\hline US-SRM & 200420052006 \\
\hline US-Ton & 200120022003200420052006 \\
\hline US-UMB & 19992000200120022003 \\
\hline US-Var & 200120022003200420052006 \\
\hline US-WCr & 19992000200120022003200420052006 \\
\hline US-Wi1 & 2003 \\
\hline US-Wi2 & 2003 \\
\hline US-Wi4 & 200320042005 \\
\hline US-Wi5 & 2004 \\
\hline US-Wi9 & 20042005 \\
\hline US-Wkg & 200420052006 \\
\hline US-Wrc & 19981999200020012002200420052006 \\
\hline VU-Coc & 2001200220032004 \\
\hline
\end{tabular}




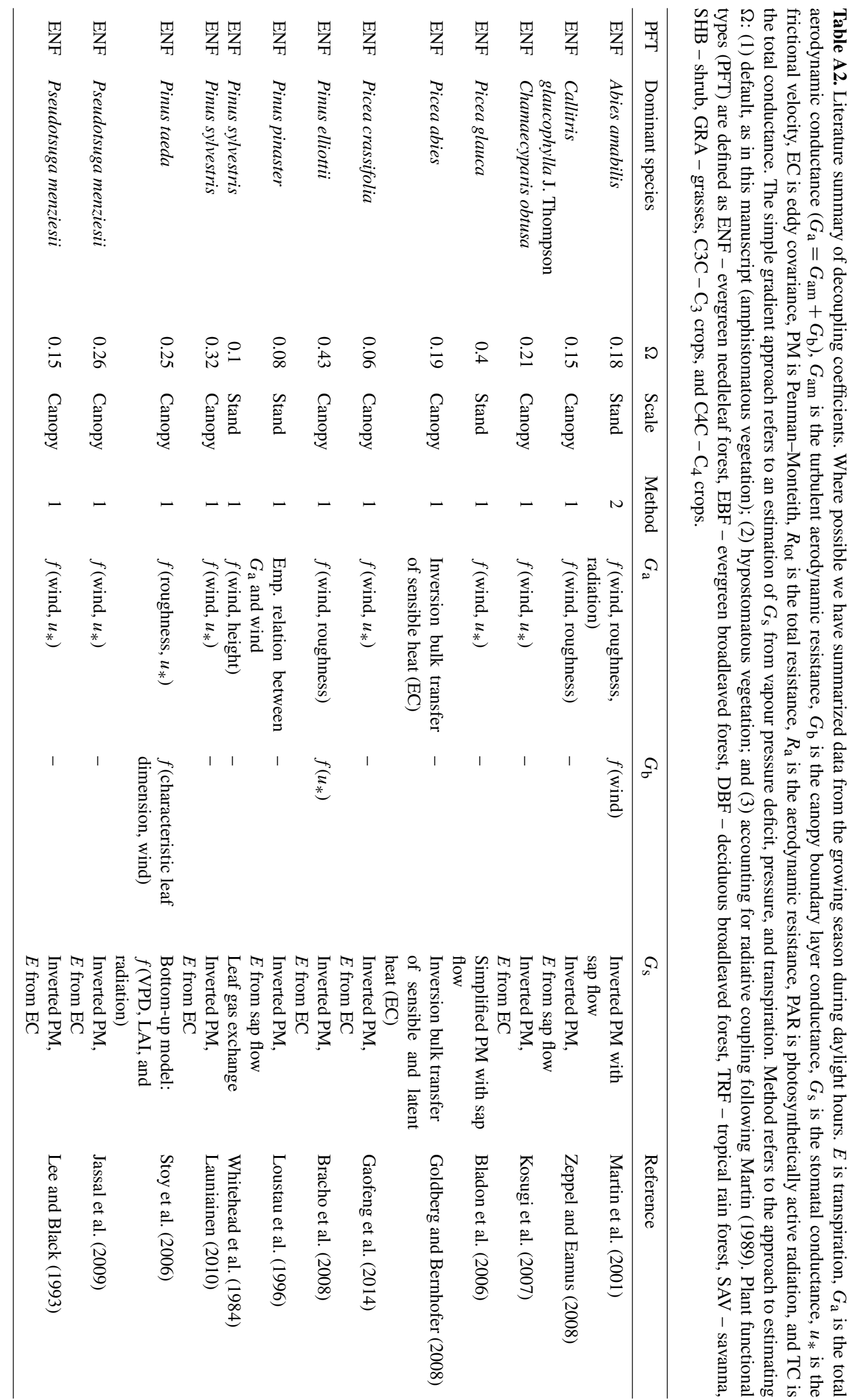




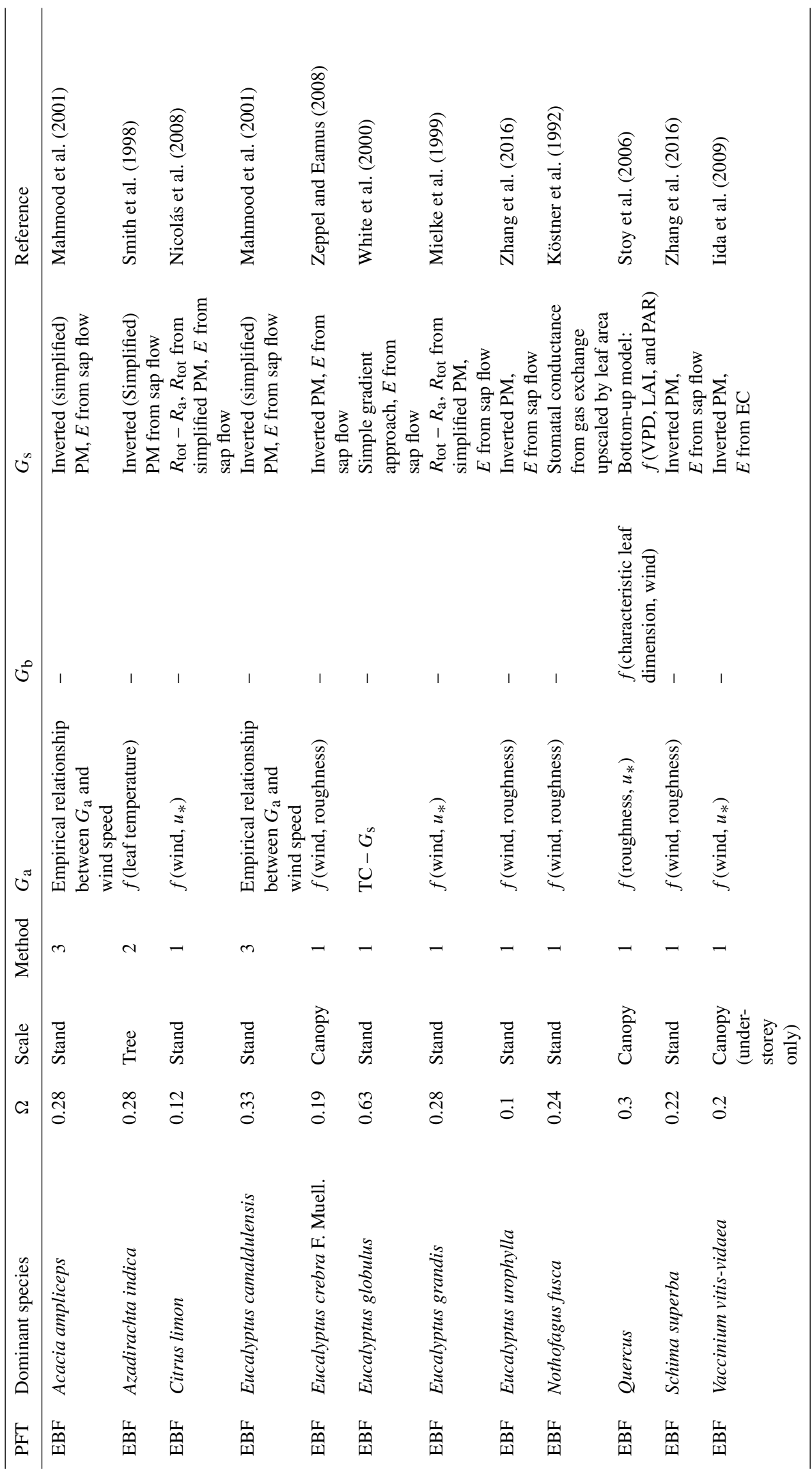



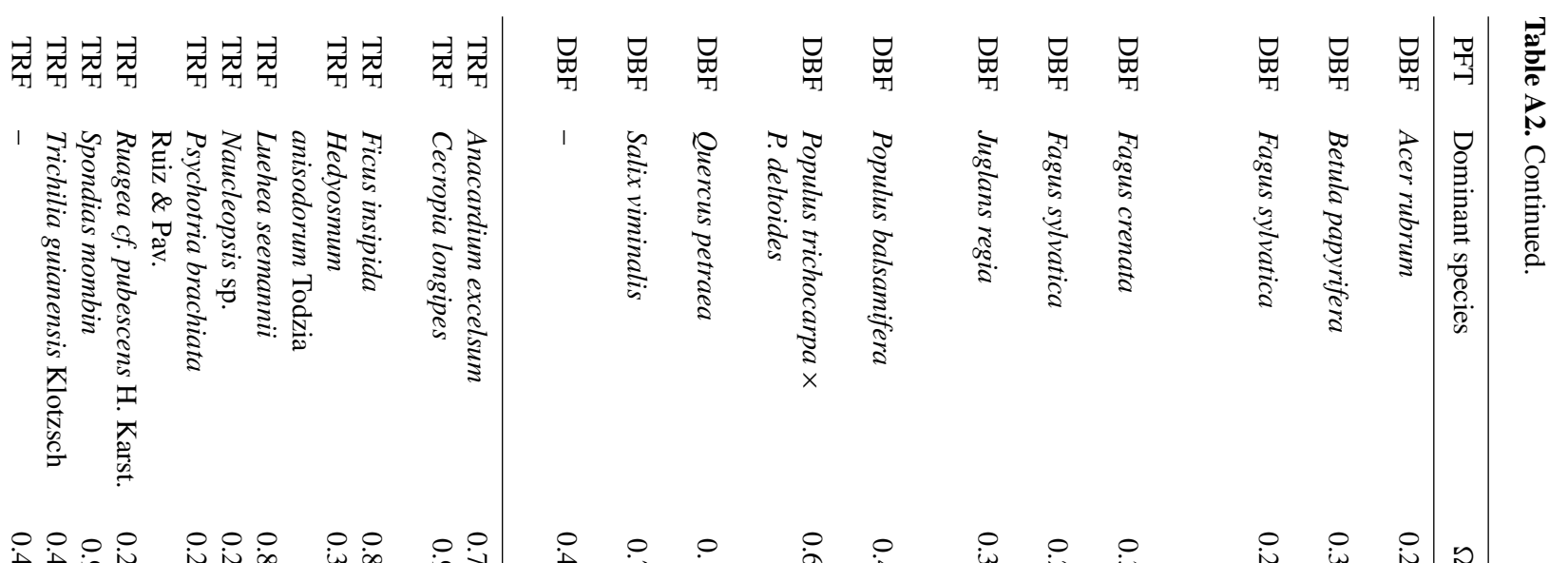

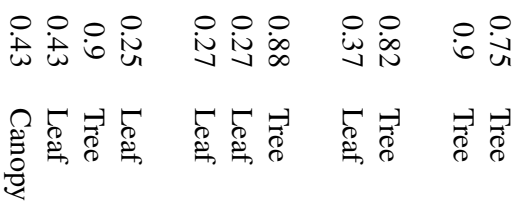

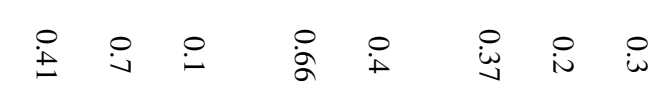

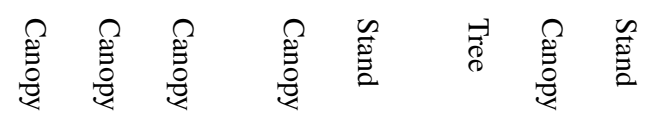
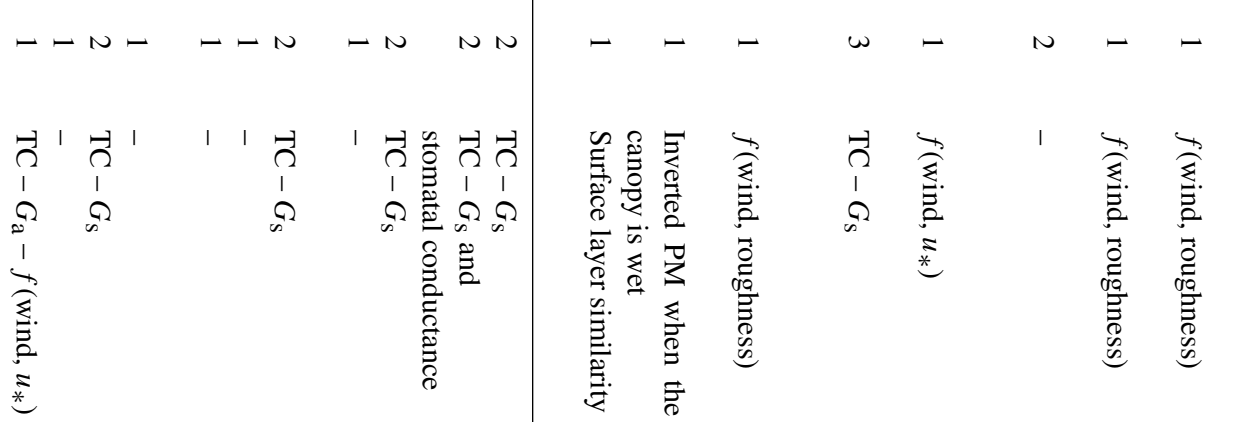

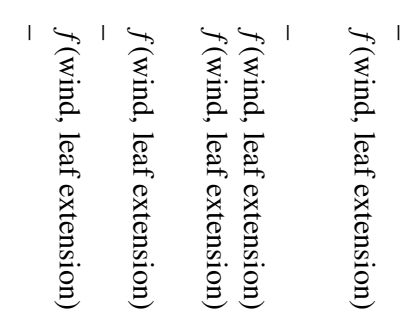

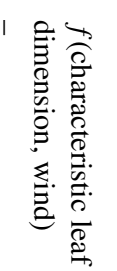

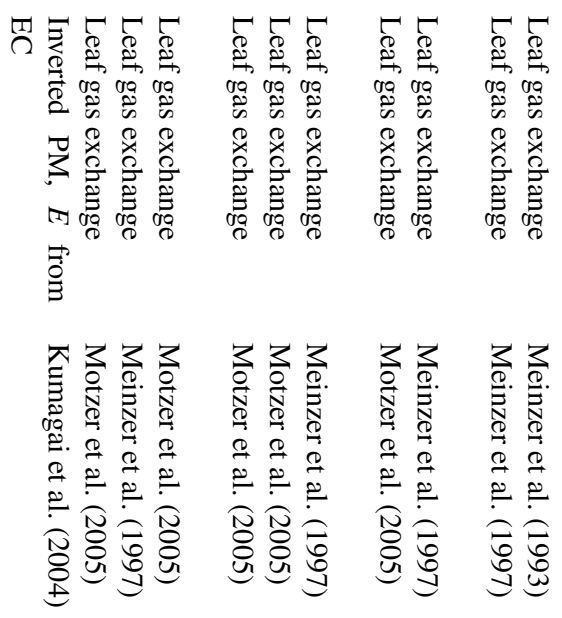

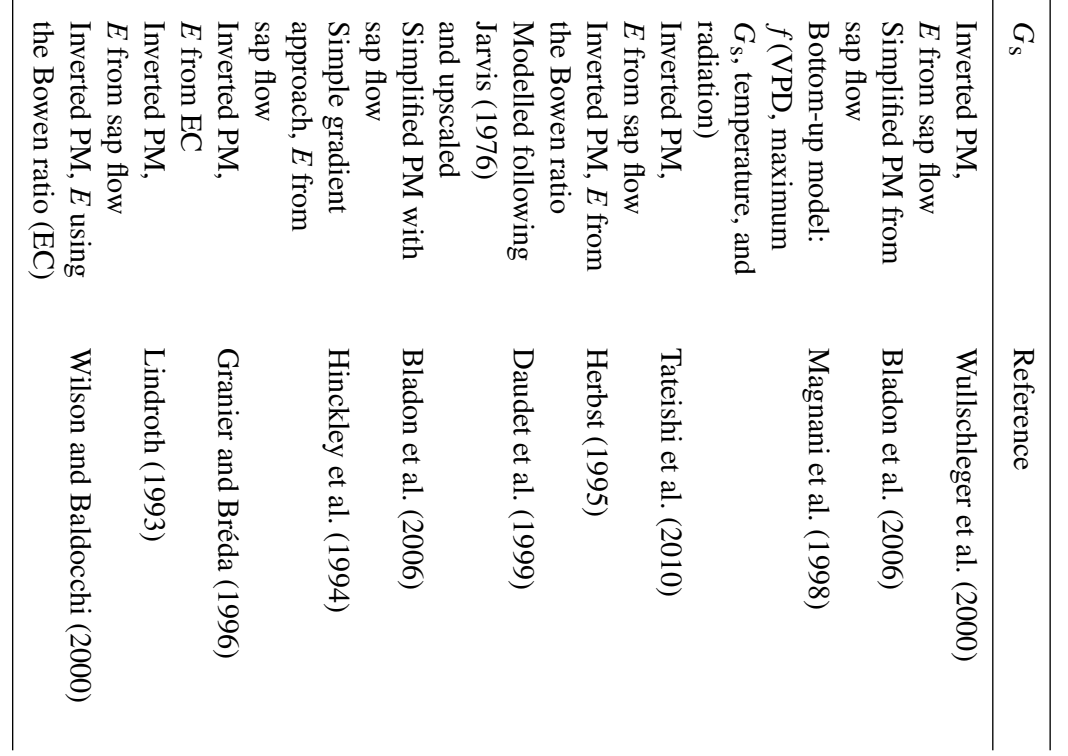




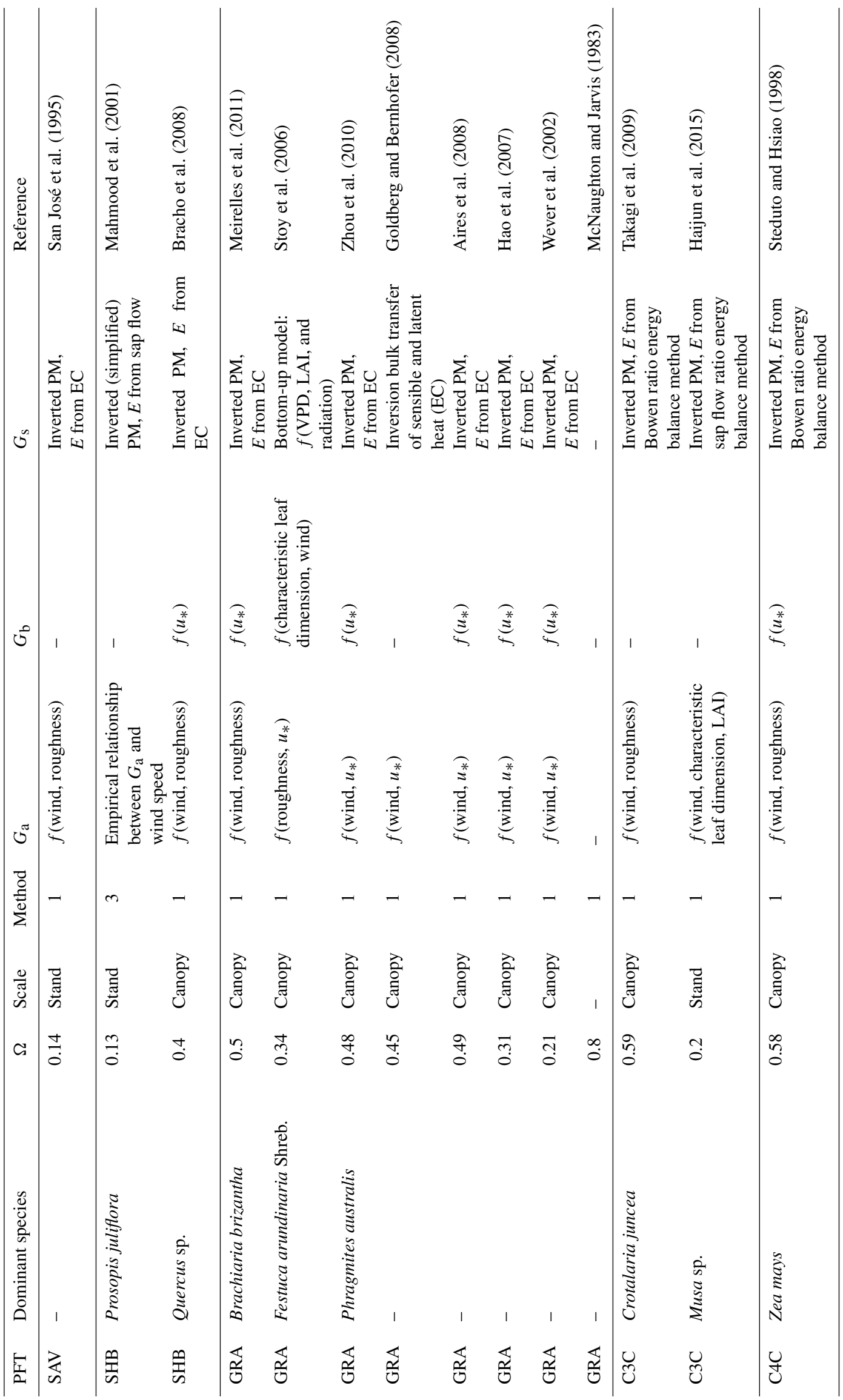


Competing interests. The authors declare that they have no conflict of interest.

Acknowledgements. Martin G. De Kauwe was supported by an Australian Research Council (ARC) Linkage grant LP140100232 and acknowledges support from the ARC Centre of Excellence for Climate System Science CE110001028. This work used eddy covariance data acquired by the FLUXNET community and in particular by the following networks: AmeriFlux (US Department of Energy, Biological and Environmental Research, Terrestrial Carbon Program; DE-FG02-04ER63917 and DE-FG0204ER63911), AfriFlux, AsiaFlux, CarboAfrica, CarboEuropeIP, CarboItaly, CarboMont, ChinaFlux, FLUXNET Canada (supported by CFCAS, NSERC, BIOCAP, Environment Canada, and NRCan), GreenGrass, KoFlux, LBA, NECC, OzFlux, TCOS Siberia, and USCCC. We acknowledge financial support for the eddy covariance data harmonization provided by CarboEuropeIP, FAO-GTOSTCO, iLEAPS, the Max Planck Institute for Biogeochemistry, the National Science Foundation, the University of Tuscia, Université Laval and Environment Canada, and the US Department of Energy. We also acknowledge contributions for the database development and technical support from the Berkeley Water Center, Lawrence Berkeley National Laboratory, Microsoft Research eScience, Oak Ridge National Laboratory, the University of California, and the University of Virginia. Finally, we thank the two anonymous reviewers for their constructive criticisms that improved this work.

Edited by: David Bowling

Reviewed by: two anonymous referees

\section{References}

Ainsworth, E. and Rogers, A.: The response of photosynthesis and stomatal conductance to rising $\left[\mathrm{CO}_{2}\right]$ : mechanisms and environmental interactions, Plant Cell Environ., 30, 258-270, https://doi.org/10.1111/j.1365-3040.2007.01641.x, 2007.

Aires, L., Pio, C., and Pereira, J.: The effect of drought on energy and water vapour exchange above a mediterranean $\mathrm{C}_{3} / \mathrm{C}_{4}$ grassland in Southern Portugal, Agr. Forest Meteorol., 148, 565-579, 2008.

Best, M. J., Pryor, M., Clark, D. B., Rooney, G. G., Essery, R. L. H., Ménard, C. B., Edwards, J. M., Hendry, M. A., Porson, A., Gedney, N., Mercado, L. M., Sitch, S., Blyth, E., Boucher, O., Cox, P. M., Grimmond, C. S. B., and Harding, R. J.: The Joint UK Land Environment Simulator (JULES), model description Part 1: Energy and water fluxes, Geosci. Model Dev., 4, 677-699, https://doi.org/10.5194/gmd-4-677-2011, 2011.

Betts, R., Boucher, O., Collins, M., Cox, P., Falloon, P., Gedney, N., Hemming, D., Huntingford, C., Jones, C., Sexton, D., and Webb, M. J.: Projected increase in continental runoff due to plant responses to increasing carbon dioxide, Nature, 448, 1037-1041, 2007.

Black, T. A., Tanner, C., and Gardner, W.: Evapotranspiration from a snap bean crop, Agron. J., 62, 66-69, 1970.

Bladon, K. D., Silins, U., Landhäusser, S. M., and Lieffers, V. J.: Differential transpiration by three boreal tree species in response to increased evaporative demand after variable retention harvesting, Agr. Forest Meteorol., 138, 104-119, 2006.

Bracho, R., Powell, T. L., Dore, S., Li, J., Hinkle, C. R., and Drake, B. G.: Environmental and biological controls on water and energy exchange in Florida scrub oak and pine flatwoods ecosystems, J. Geophys. Res.-Biogeo., 113, G02004, https://doi.org/10.1029/2007JG000469, 2008.

Brown, K. W.: Vegetation and the Atmosphere, Sugar beet and potatoes, Academic Press, London, 1976.

Cao, L., Bala, G., Caldeira, K., Nemani, R., and Ban-Weiss, G.: Importance of carbon dioxide physiological forcing to future climate change, Proc. Natl. Acad. Sci. USA, 107, 9513-9518, https://doi.org/10.1073/pnas.0913000107, 2010.

Daudet, F., Le Roux, X., Sinoquet, H., and Adam, B.: Wind speed and leaf boundary layer conductance variation within tree crown: consequences on leaf-to-atmosphere coupling and tree functions, Agr. Forest Meteorol., 97, 171-185, 1999.

De Kauwe, M. G., Medlyn, B. E., Zaehle, S., Walker, A. P., Dietze, M. C., Hickler, T., Jain, A. K., Luo, Y., Parton, W. J., Prentice, I. C., Smith, B., Thornton, P. E., Wang, S., Wang, Y.-P., Wårlind, D., Weng, E., Crous, K. Y., Ellsworth, D. S., Hanson, P. J., Seok Kim, H., Warren, J. M., Oren, R., and Norby, R. J.: Forest water use and water use efficiency at elevated $\mathrm{CO}_{2}$ : a model-data intercomparison at two contrasting temperate forest FACE sites, Glob. Change Biol., 19, 1759-1779, https://doi.org/10.1111/gcb.12164, 2013.

De Kauwe, M. G., Kala, J., Lin, Y.-S., Pitman, A. J., Medlyn, B. E., Duursma, R. A., Abramowitz, G., Wang, Y.-P., and Miralles, D. G.: A test of an optimal stomatal conductance scheme within the CABLE land surface model, Geosci. Model Dev., 8, 431452, https://doi.org/10.5194/gmd-8-431-2015, 2015.

Dekker, S. C., Groenendijk, M., Booth, B. B. B., Huntingford, C., and Cox, P. M.: Spatial and temporal variations in plant water-use efficiency inferred from tree-ring, eddy covariance and atmospheric observations, Earth Syst. Dynam., 7, 525-533, https://doi.org/10.5194/esd-7-525-2016, 2016.

Foken, T.: The energy balance closure problem: an overview, Ecol. Appl., 18, 1351-1367, 2008.

Gaofeng, Z., Ling, L., Yonghong, S., Xufeng, W., Xia, C., Jinzhu, M., Jianhua, H., Kun, Z., and Changbin, L.: Energy flux partitioning and evapotranspiration in a sub-alpine spruce forest ecosystem, Hydrol. Proc., 28, 5093-5104, 2014.

Gedney, N., Cox, P., Betts, R., Boucher, O., Huntingford, C., and Stott, P.: Detection of a direct carbon dioxide effect in continental river runoff records, Nature, 439, 835-838, https://doi.org/10.1038/nature04504, 2006.

Goldberg, V. and Bernhofer, C.: Testing different decoupling coefficients with measurements and models of contrasting canopies and soil water conditions, Ann. Geophys., 26, 1977-1992, https://doi.org/10.5194/angeo-26-1977-2008, 2008.

Granier, A. and Bréda, N.: Modelling canopy conductance and stand transpiration of an oak forest from sap flow measurements, Ann. Sci. Forest., 53, 537-546, 1996.

Groenendijk, M., Dolman, A., van der Molen, M., Leuning, R., Arneth, A., Delpierre, N., Gash, J., Lindroth, A., Richardson, A., Verbeeck, H., and Wohlfahrt, G.: Assessing parameter variability in a photosynthesis model within and between plant functional types using global Fluxnet eddy covariance data, Agr. Forest Meteorol., 151, 22-38, 2011. 
Haijun, L., Cohen, S., Lemcoff, J. H., Israeli, Y., and Tanny, J.: Sap flow, canopy conductance and microclimate in a banana screenhouse, Agr. Forest Meteorol., 201, 165-175, 2015.

Hao, Y., Wang, Y., Huang, X., Cui, X., Zhou, X., Wang, S., Niu, H., and Jiang, G.: Seasonal and interannual variation in water vapor and energy exchange over a typical steppe in Inner Mongolia, China, Agr. Forest Meteorol., 146, 57-69, 2007.

Herbst, M.: Stomatal behaviour in a beech canopy: an analysis of Bowen ratio measurements compared with porometer data, Plant Cell Environ., 18, 1010-1018, 1995.

Hinckley, T., Brooks, J., Čermák, J., Ceulemans, R., Kučera, J., Meinzer, F., and Roberts, D.: Water flux in a hybrid poplar stand, Tree Physiol., 14, 1005-1018, 1994.

Huntingford, C. and Monteith, J.: The behaviour of a mixed-layer model of the convective boundary layer coupled to a big leaf model of surface energy partitioning, Bound.-Lay. Meteorol., 88, 87-101, 1998.

Iida, S., Ohta, T., Matsumoto, K., Nakai, T., Kuwada, T., Kononov, A. V., Maximov, T. C., van der Molen, M. K., Dolman, H., Tanaka, H., and Yabuki, H.: Evapotranspiration from understory vegetation in an eastern Siberian boreal larch forest, Agr. Forest Meteorol., 149, 1129-1139, 2009.

Jacobs, C. and De Bruin, H.: The sensitivity of regional transpiration to land-surface characteristics: significance of feedback, J. Clim., 5, 683-698, 1992.

Jarvis, P.: The interpretation of the variations in leaf water potential and stomatal conductance found in canopies in the field, Philos. T. R. Soc. Lond., 273, 593-610, 1976.

Jarvis, P. and McNaughton, K.: Stomatal control of transpiration: Scaling up from leaf to region, Adv. Ecol. Res., 15, 1-49, 1986.

Jarvis, P. G.: Attributes of Trees as Crop Plants, Transpiration and assimilation of tree and agricultural crops: the omega factor, 460-480, Institute of Terrestrial Ecology, 1985.

Jassal, R. S., Black, T. A., Spittlehouse, D. L., Brümmer, C., and Nesic, Z.: Evapotranspiration and water use efficiency in different-aged Pacific Northwest Douglas-fir stands, Agr. Forest Meteorol., 149, 1168-1178, 2009.

Khatun, R., Ohta, T., Kotani, A., Asanuma, J., Gamo, M., Han, S., Hirano, T., Nakai, Y., Saigusa, N., Takagi, K., Wang, H., and Yoshifuji, N.: Spatial variations in evapotranspiration over East Asian forest sites, I. Evapotranspiration and decoupling coefficient, Hydrol. Res. Lett., 5, 83-87, 2011.

Knauer, J., Zaehle, S., Medlyn, B., Reichstein, M., Williams, C. A., Migliavacca, M., De Kauwe, M. G., Werner, C., Keitel, C., Kolari, P., Limousin, J.-M., and Linderson, M.J.: Towards physiologically meaningful water-use efficiency estimates from eddy covariance data, Glob. Change Biol., https://doi.org/10.1111/gcb.13893, 2017.

Köstner, B., Schulze, E.-D., Kelliher, F., Hollinger, D., Byers, J., Hunt, J., McSeveny, T., Meserth, R., and Weir, P.: Transpiration and canopy conductance in a pristine broad-leaved forest of Nothofagus: an analysis of xylem sap flow and eddy correlation measurements, Oecologia, 91, 350-359, 1992.

Kosugi, Y., Takanashi, S., Tanaka, H., Ohkubo, S., Tani, M., Yano, M., and Katayama, T.: Evapotranspiration over a Japanese cypress forest, I. Eddy covariance fluxes and surface conductance characteristics for 3 years, J. Hydrol., 337, 269-283, 2007.

Kowalczyk, E. A., Wang, Y. P., Wang, P., Law, R. H., and Davies, H. L.: The CSIRO Atmosphere Biosphere Land Exchange (CA-
BLE) model for use in climate models and as an offline model, Tech. Rep. CSIRO Marine and Atmospheric Research paper 013, CSIRO, CABLE model, 2006.

Kumagai, T., Saitoh, T. M., Sato, Y., Morooka, T., Manfroi, O. J., Kuraji, K., and Suzuki, M.: Transpiration, canopy conductance and the decoupling coefficient of a lowland mixed dipterocarp forest in Sarawak, Borneo: dry spell effects, J. Hydrol., 287, 237251, 2004.

Launiainen, S.: Seasonal and inter-annual variability of energy exchange above a boreal Scots pine forest, Biogeosciences, 7, 3921-3940, https://doi.org/10.5194/bg-7-3921-2010, 2010.

Law, B., Falge, E., Gu, L. v., Baldocchi, D., Bakwin, P., Berbigier, P., Davis, K., Dolman, A., Falk, M., Fuentes, J., Goldstein, A., Granier, A., Grelle, A., Hollinger, D., Janssens, I. A., Jarvis, P., Jensen, N. O., Katul, G., Mahli, Y., Matteucci, G., Meyers, T., Monson, R., Munger, W., Oechel, W., Olson, R., Pilegaard, K., Paw, U. K. T., Thorgeirsson, H., Valentini, R., Verma, S., Vesala, T., Wilson, K., and Wofsy, S.: Environmental controls over carbon dioxide and water vapor exchange of terrestrial vegetation, Agr. Forest Meteorol., 113, 97-120, 2002.

Lee, X. and Black, T. A.: Atmospheric turbulence within and above a Douglas-fir stand. Part II: Eddy fluxes of sensible heat and water vapour, Bound.-Lay. Meteorol., 64, 369-389, 1993.

Lin, Y.-S., Medlyn, B. E., Duursma, R. A., Prentice, I. C., Wang, H., Baig, S., Eamus, D., de Dios, V. R., Mitchell, P., Ellsworth, D. S., de Beeck, M. O., Wallin, G., Uddling, J., Tarvainen, L., Linderson, M.-L., Cernusak, L. A., Nippert, J. B., Ocheltree, T. W., Tissue, D. T., Martin-StPaul, N. K., Rogers, A., Warren, J. M., De Angelis, P., Hikosaka, K., Han, Q., Onoda, Y., Gimeno, T. E., Barton, C. V. M., Bennie, J., Bonal, D., Bosc, A., Low, M., Macinins-Ng, C., Rey, A., Rowland, L., Setterfield, S. A., TauszPosch, S., Zaragoza-Castells, J., Broadmeadow, M. S. J., Drake, J. E., Freeman, M., Ghannoum, O., Hutley, L. B., Kelly, J. W., Kikuzawa, K., Kolari, P., Koyama, K., Limousin, J.-M., Meir, P., Lola da Costa, A. C., Mikkelsen, T. N., Salinas, N., Sun, W., and Wingate, L.: Optimal stomatal behaviour around the world, Nature Climate Change, 5, 459-464, 2015.

Lindroth, A.: Aerodynamic and canopy resistance of short-rotation forest in relation to leaf area index and climate, Bound.-Lay. Meteorol., 66, 265-279, 1993.

Loustau, D., Berbigier, P., Roumagnac, P., Arruda-Pacheco, C., David, J., Ferreira, M., Pereira, J., and Tavares, R.: Transpiration of a 64-year-old maritime pine stand in Portugal, Oecologia, 107, 33-42, 1996.

Magnani, F., Leonardi, S., Tognetti, R., Grace, J., and Borghetti, M.: Modelling the surface conductance of a broad-leaf canopy: effects of partial decoupling from the atmosphere, Plant Cell Environ., 21, 867-879, 1998.

Mahmood, K., Morris, J., Collopy, J., and Slavich, P.: Groundwater uptake and sustainability of farm plantations on saline sites in Punjab province, Pakistan, Agr. Water Manage., 48, 1-20, 2001.

Martin, P.: The significance of radiative coupling between vegetation and the atmosphere, Agr. Forest Meteorol., 49, 45-53, 1989.

Martin, T., Brown, K., Kučera, J., Meinzer, F., Sprugel, D., and Hinckley, T.: Control of transpiration in a 220-year-old Abies amabilis forest, Forest Ecol. Manag., 152, 211-224, 2001.

McElwain, J. C. and Chaloner, W. G.: Stomatal density and index of fossil plants track atmospheric carbon dioxide in the Palaeozoic, Ann. Bot.-London, 76, 389-395, 1995. 
McNaughton, K. and Jarvis, P.: Water Deficits and Plant Growth, Predicting effects of vegetation changes on transpiration and evaporation, Academic Press, San Diego, Vol. VII, 1-47, 1983.

McNaughton, K. and Jarvis, P.: Effects of spatial scale on stomatal control of transpiration, Agr. Forest Meteorol., 54, 279-302, 1991.

Medlyn, B., Barton, C., Broadmeadow, M., Ceulemans, R., De Angelis, P., Forstreuter, M., Freeman, M., Jackson, S., Kellomaki, S., Laitat, E., Rey, A., Roberntz, P., Sigurdsson, B., Strassemeyer, J., Wang, K., Curtis, P., and Jarvis, P.: Stomatal conductance of forest species after long-term exposure to elevated $\mathrm{CO}_{2}$ concentration: a synthesis, New Phytol., 149, 247-264, 2001.

Medlyn, B. E., De Kauwe, M. G., Lin, Y.-S., Knauer, J., Duursma, R. A., Williams, C. A., Arneth, A., Clement, R., Isaac, P., Limousin, J.-M., Linderson, M.-L., Meir, P., MartinStPaul, N., and Wingate, L.: How do leaf and ecosystem measures of water-use efficiency compare?, New Phytol., https://doi.org/10.1111/nph.14626, 2017.

Meinzer, F., Goldstein, G., Holbrook, N., Jackson, P., and Cavelier, J.: Stomatal and environmental control of transpiration in a lowland tropical forest tree, Plant Cell Environ., 16, 429-436, 1993.

Meinzer, F., Andrade, J., Goldstein, G., Holbrook, N., Cavelier, J., and Jackson, P.: Control of transpiration from the upper canopy of a tropical forest: the role of stomatal, boundary layer and hydraulic architecture components, Plant Cell Environ., 20, 12421252, 1997.

Meirelles, M., Franco, A., Farias, S., and Bracho, R.: Evapotranspiration and plant-atmospheric coupling in a Brachiaria brizantha pasture in the Brazilian savannah region, Grass and Forage Science, 66, 206-213, 2011.

Mielke, M. S., Oliva, M., de Barros, N. F., Penchel, R. M., Martinez, C. A., and de Almeida, A. C.: Stomatal control of transpiration in the canopy of a clonal Eucalyptus grandis plantation, TreesStruct. Funct., 13, 152-160, 1999.

Miner, G. L., Bauerle, W. L., and Baldocchi, D. D.: Estimating the sensitivity of stomatal conductance to photosynthesis: A review, Plant Cell Environ., 40, 1214-1238, 2017.

Morison, J. I. L.: Sensitivity of stomata and water use efficiency to high $\mathrm{CO}_{2}$, Plant Cell Environ., 8, 467-474, 1985.

Motzer, T., Munz, N., Küppers, M., Schmitt, D., and Anhuf, D.: Stomatal conductance, transpiration and sap flow of tropical montane rain forest trees in the southern Ecuadorian Andes, Tree Physiol., 25, 1283-1293, 2005.

Nicolás, E., Barradas, V., Ortuño, M., Navarro, A., Torrecillas, A., and Alarcón, J.: Environmental and stomatal control of transpiration, canopy conductance and decoupling coefficient in young lemon trees under shading net, Environ. Exp. Bot., 63, 200-206, 2008.

Oleson, K. W., Lawrence, D. M., Bonan, G. B., Drewniak, B., Huang, M., Koven, C. D., Levis, S., Li, F., Riley, W. J., Subin, Z. M., Swenson, S. C., Thornton, P. E., Bozbiyik, A., Fisher, R., Heald, C. L., Kluzek, E., Lamarque, J.-F., Lawrence, P. J., Leung, L. R., Lipscomb, W., Muszala, S., Ricciuto, D. M., Sacks, W., Sun, Y., Tang, J., and Yang, Z.-L.: Technical Description of version 4.5 of the Community Land Model (CLM), NCAR Technical Note NCAR/TN-503+STR, National Center for Atmospheric Research. Climate and Global Dynamics Division, National Center for Atmospheric Research, P.O. Box 3000, Boulder, Colarado, 2013.
Raupach, M. and Finnigan, J.: Single-layer models of evaporation from plant canopies are incorrect but useful, whereas multilayer models are correct but useless, Funct. Plant Biol., 15, 705-716, 1988.

Raupach, M., Finkele, K., and Zhang, L.: SCAM (Soil-CanopyAtmosphere Model): Description and comparison with field data, Aspendale, Australia: CSIRO CEM Technical Report, p. 81, 1997.

San José, J. J., Montes, R. A., and Florentino, A.: Water flux through a semi-deciduous forest grove of the Orinoco savannas, Oecologia, 101, 141-150, 1995.

Sánchez, J. M., Caselles, V., and Rubio, E. M.: Analysis of the energy balance closure over a FLUXNET boreal forest in Finland, Hydrol. Earth Syst. Sci., 14, 1487-1497, https://doi.org/10.5194/hess-14-1487-2010, 2010.

Sitch, S., Smith, B., Prentice, I. C., Arneth, A., Bondeau, A., Cramer, W., Kaplan, J., Levis, S., Lucht, W., Sykes, M., Thonicke, K., and Venevski, S.: Evaluation of ecosystem dynamics, plant geography and terrestrial carbon cycling in the LPJ Dynamic Vegetation Model, Glob. Change Biol., 9, 161-185, 2003.

Smith, D., Jarvis, P., and Odongo, J.: Management of windbreaks in the Sahel: the strategic implications of tree water use, Agroforest. Syst., 40, 83-96, 1998.

Steduto, P. and Hsiao, T. C.: Maize canopies under two soil water regimes: III. Variation in coupling with the atmosphere and the role of leaf area index, Agr. Forest Meteorol., 89, 201-213, 1998.

Stoy, P., Katul, G., Siqueira, M., Juang, J., Novick, K., Mccarthy, H., Christopher Oishi, A., Uebelherr, J., Kim, H., and Oren, R.: Separating the effects of climate and vegetation on evapotranspiration along a successional chronosequence in the southeastern US, Glob. Change Biol., 12, 2115-2135, 2006.

Su, Z., Schmugge, T., Kustas, W., and Massman, W.: An evaluation of two models for estimation of the roughness height for heat transfer between the land surface and the atmosphere, J. Appl. Meteorol., 40, 1933-1951, 2001.

Takagi, K., Kimura, R., and Şaylan, L.: Variability of surface characteristics and energy flux patterns of sunn hemp (Crotalaria juncea L.) under well-watered conditions, Theor. Appl. Climatol., 96, 261-273, 2009.

Tateishi, M., Kumagai, T., Suyama, Y., and Hiura, T.: Differences in transpiration characteristics of Japanese beech trees, Fagus crenata, in Japan, Tree Physiol., 30, 748-760, 2010.

Thom, A. S.: Vegetation and the Atmosphere, chap. Momentum, Mass and Heat Exchange of Plant Communities, Academic Press, London, 57-109, 1975.

Wever, L. A., Flanagan, L. B., and Carlson, P. J.: Seasonal and interannual variation in evapotranspiration, energy balance and surface conductance in a northern temperate grassland, Agr. Forest Meteorol., 112, 31-49, 2002.

White, D., Beadle, C., and Worledge, D.: Control of transpiration in an irrigated Eucalyptus globulus Labill. plantation, Plant Cell Environ., 23, 123-134, 2000.

Whitehead, D., Jarvis, P. G., and Waring, R. H.: Stomatal conductance, transpiration, and resistance to water uptake in a Pinus sylvestris spacing experiment, Can. J. Forest Res., 14, 692-700, 1984.

Williams, C. A., Reichstein, M., Buchmann, N., Baldocchi, D., Beer, C., Schwalm, C., Wohlfahrt, G., Hasler, N., Bernhofer, C., Foken, T., Papale, D., Schymanski, S., and Schaefer, K.: 
Climate and vegetation controls on the surface water balance: Synthesis of evapotranspiration measured across a global network of flux towers, Water Resour. Res., 48, W06523, https://doi.org/10.1029/2011WR011586, 2012.

Wilson, K., Goldstein, A., Falge, E., Aubinet, M., Baldocchi, D., Berbigier, P., Bernhofer, C., Ceulemans, R., Dolman, H., Field, C., Grelle, A., Ibrom, A., Law, B. E., Kowalski, A., Meyers, T., Moncrieff, J., Monson, R., Oechel, W., Tenhunen, J., Valentini, R., and Verma, S.: Energy balance closure at FLUXNET sites, Agr. Forest Meteorol., 113, 223-243, 2002.

Wilson, K. B. and Baldocchi, D. D.: Seasonal and interannual variability of energy fluxes over a broadleaved temperate deciduous forest in North America, Agr. Forest Meteorol., 100, 1-18, 2000.

Wohlfahrt, G., Haslwanter, A., Hörtnagl, L., Jasoni, R. L., Fenstermaker, L. F., Arnone, J. A., and Hammerle, A.: On the consequences of the energy imbalance for calculating surface conductance to water vapour, Agr. Forest Meteorol., 149, 1556-1559, 2009.

Woodward, F. and Kelly, C.: The influence of $\mathrm{CO}_{2}$ concentration on stomatal density, New Phytol., 131, 311-327, 1995.

Woodward, F. I., Smith, T. M., and Emanuel, W. R.: A global land primary productivity and phytogeography model, Global Biogeochem. Cy., 9, 471-490, 1995.

Wullschleger, S. D., Meinzer, F., and Vertessy, R.: A review of whole-plant water use studies in tree, Tree Physiol., 18, 499-512, 1998.
Wullschleger, S. D., Wilson, K. B., and Hanson, P. J.: Environmental control of whole-plant transpiration, canopy conductance and estimates of the decoupling coefficient for large red maple trees, Agr. Forest Meteorol., 104, 157-168, 2000.

Zeppel, M. and Eamus, D.: Coordination of leaf area, sapwood area and canopy conductance leads to species convergence of tree water use in a remnant evergreen woodland, Aust. J. Bot., 56, 97 108, 2008.

Zhang, Z. Z., Zhao, P., McCarthy, H. R., Zhao, X. H., Niu, J. F., Zhu, L. W., Ni, G. Y., Ouyang, L., and Huang, Y. Q.: Influence of the decoupling degree on the estimation of canopy stomatal conductance for two broadleaf tree species, Agr. Forest Meteorol., 221, 230-241, 2016.

Zhou, L., Zhou, G., Liu, S., and Sui, X.: Seasonal contribution and interannual variation of evapotranspiration over a reed marsh (Phragmites australis) in Northeast China from 3-year eddy covariance data, Hydrol. Process., 24, 1039-1047, 2010.

Zhu, P., Zhuang, Q., Ciais, P., Welp, L., Li, W., and Xin, Q.: Elevated atmospheric $\mathrm{CO}_{2}$ negatively impacts photosynthesis through radiative forcing and physiology-mediated climate feedback, Geophys. Res. Lett., 44, 1956-1963, https://doi.org/0.1002/2016GL071733, 2017. 